\title{
pnmbalina
}

(8)

\section{A multidisciplinary network: perspective on the doma in of psychological violence in conjugality: part 1}

\author{
Autor(es): $\quad$ Garcia, P. \\ Publicado por: Imprensa da Universidade de Coimbra; International Academy of Legal \\ Medicine \\ URL \\ persistente: \\ URI:http://hdl.handle.net/10316.2/31815 \\ DOI: \\ DOI:http://dx.doi.org/10.14195/978-989-26-0173-1_40 \\ Accessed : $\quad$ 26-Apr-2023 15:31:00
}

A navegação consulta e descarregamento dos títulos inseridos nas Bibliotecas Digitais UC Digitalis, UC Pombalina e UC Impactum, pressupõem a aceitação plena e sem reservas dos Termos e Condições de Uso destas Bibliotecas Digitais, disponíveis em https://digitalis.uc.pt/pt-pt/termos.

Conforme exposto nos referidos Termos e Condições de Uso, o descarregamento de títulos de acesso restrito requer uma licença válida de autorização devendo o utilizador aceder ao(s) documento(s) a partir de um endereço de IP da instituição detentora da supramencionada licença.

Ao utilizador é apenas permitido o descarregamento para uso pessoal, pelo que o emprego do(s) título(s) descarregado(s) para outro fim, designadamente comercial, carece de autorização do respetivo autor ou editor da obra.

Na medida em que todas as obras da UC Digitalis se encontram protegidas pelo Código do Direito de Autor e Direitos Conexos e demais legislação aplicável, toda a cópia, parcial ou total, deste documento, nos casos em que é legalmente admitida, deverá conter ou fazer-se acompanhar por este aviso.

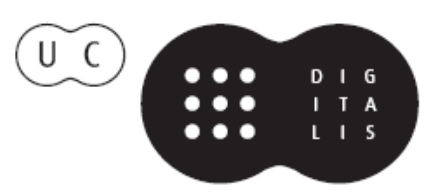




\section{Duarte Nuno Vieira Anthony Busuttil \\ Denis Cusack • Philip Beth}
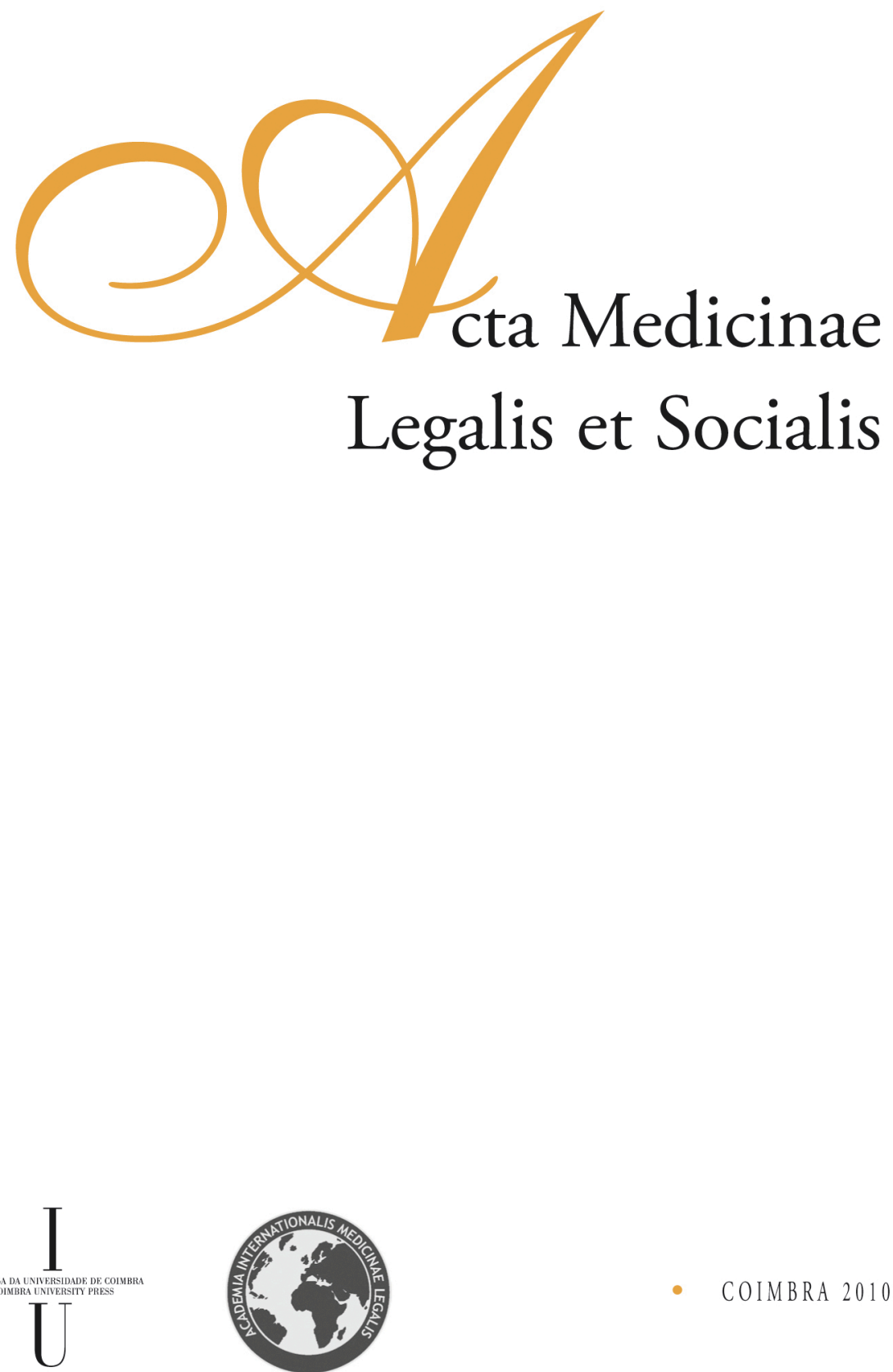


\title{
P. Garcia
}

Public Prosecutor at Department of Investigation and Penal Action (DIAP)

Department of Justice, Coimbra, Portugal

\section{A MULTIDISCIPLINARY NETWORK: PERSPECTIVE ON THE DOMAIN OF PSYCHOLOGICAL VIOLENCE IN CONJUGALITY - PART 1}

\begin{abstract}
Domestic Violence generates hard conditions for the abused ones. Damages can be either physical or psychological. For Judiciary purposes it is fundamental to establish causeconnection and to evaluate the risk rate for every case. Thus, the role of Legal Medicine becomes crucial for Judiciary work as well as the Psychiatric and Psychological health care services in terms of risk evaluation and curing approaches. The multidisciplinary approach is needed. A successful experienced at Coimbra is reported. Aiming to solve hard situations and caring for the condition of the abused ones, a network involving 11 institutions (3 judiciary, 4 health and 4 social) was set up under the name of "Grupo Violência”.
\end{abstract}

\section{Introduction}

Domestic violence is a serious problem around the world. It violates the fundamental human rights of the victims and often results in severe injury and death.

All over the world the prevalence of cases of violence against women by their partner is overwhelming. It is estimated that one, in every five European women, experienced violence and that at least seven hundred women in Europe die every year as result of violence perpetrated by an intimate partner (Athena, 2006).

Most women that die as a consequence of a homicide are murdered at home by their partners. On the contrary, men that die as a consequence of a homicide are killed outside by non relatives.

Studies show that domestic violence is the greatest motive of death and invalidity among women.

In general, the victims of domestic violence are women. However, there are also cases where the women are perpetrators of violence against men, mainly of psychological nature. Children and older people are also, often, victims of domestic violence.

It is a phenomenon that occurs within all social, economic, religious and cultural groups, and it is a reality, both in developed countries and in underdeveloped ones.

UN Declaration on Elimination of Violence against Women recommends that state members promote research, collect data and compile statistics concerning domestic violence, with the goal of understanding the problem in order to find solutions for them. 
Therefore, countries must develop policies to face the problem, such as passing adequate legislation, creating mechanisms do protect the victims from the aggressors, promoting the recuperation of the offender through special programs for aggressors.

Domestic violence involves enormous costs to treat all the symptoms and diseases caused by this kind of violence. Sometimes, those symptoms are not immediately evident and perceptible.

\section{A criminal offence}

It is a criminal offence. Neither the society, nor the judicial system, should ever regard the violence inflicted on someone by an intimate partner, less serious than the violence inflicted by a stranger. However, in spite of that, according to Amnesty International, in seventy nine countries of the world there is no legislation dealing with the matter of domestic violence.

\section{Portugal: a public crime}

In Portugal domestic violence is a public crime only since the year two thousands. It means that victims do not have the responsibility for initiating criminal charges because the State assumes this as its own duty.

All public institutions, like police, hospitals and care centres, must communicate to the Department of Justice all the cases that they identify as domestic violence. This change of the law was crucial, since it allowed that an enormous number of cases came out from the shadow and, consequently, it also allowed the corresponding criminal investigation.

Elza Pais, the President of the Portuguese Commission for Citizenship and Gender Equality, made a study about spousal murder in Portugal and she settled that, in every six homicides, one was a spousal homicide.

In 2006, two hundred and twelve men were in prison for the murder of their wives, partners or girlfriends. In 2008, forty nine women were killed in Portugal. Almost all of them were victims of domestic violence. In most cases all those women, before the murder, had a history of being battered by their partner who put an end to their life (CIG, 2007)

If one looks at the preceding story, whenever a murder occurs in a partnership relation, it will be noted that, despite the signs, nobody did anything to prevent the unhappy end.

When someone is a victim of domestic violence, it is important to make an adequate and swift intervention, regarding the aggressor, the victim and even the family, in order to prevent that more serious attempt against victims occurs, such as homicide.

Men that kill their wives, partners or girlfriends, act not moved by an impulse that occurs on that particular moment. On contrary, they kill after premeditating about it for a long period; they had thought carefully how to do things; they had threatened; they had warned the victim and yet nobody, even the victim, recognised the warning signs. But those signs where there and it was imperious that someone had to look for them.

As Mullender (2000) said "The domestic violence cases of today are often the murders of tomorrow". 


\section{The court}

A lot of complaints from victims of domestic violence are filled in the court. This is a very special crime because it occurs among people that had shared their lives for a long time, that had dreams and goals together, that had children they care about. It is very difficult for them, in one way, to recognize that their project of life has failed, as well as to face a new life, alone, with the uncertainty of the future.

Aiming to give to each crime of domestic violence an adequate response, it is fundamental to have an interdisciplinary approach, involving all the institutions that work with the phenomenon - those that investigate the crime, those that made the assessment of the victims and offenders and those that protect the victims.

While the police and the court take measures against the aggressor, the victims must be immediately supported, protected and assisted, by health and social care workers.

\section{The net work}

In order to achieve this, in Coimbra, a network has been set up which involves a lot of institutions from all areas - health, social and justice - named "Violence Group - Information, Investigation and Intervention”.

This Group is trying to find and to develop strategies to prevent domestic violence throughout an articulated work. It is also committed to bring to the surface the shadow sides of violence and victimization.

The public hospital is the entrance door of a lot of cases of domestic violence, which are camouflaged as downfall and accidents, what means that an inappropriate cause has been mentioned.

Nurses and doctors in the emergency departments are on the front line of interpersonal violence and are in a vital and unique position to initiate the process that may stop the cycle of violence (Healey, 1998).

Because of this, at the emergency rooms of the Central Hospital in Coimbra it is now being developed a program to implement the screening of victims of domestic violence, to collect all physical and psychological evidence and to give to the victims a special treatment in order to protect and support them.

\section{Legal Medicine}

Legal Medicine is an interface between the health care system and the legal system.

The National Institute of Legal Medicine is a national reference and it is the official entity that cooperates with the courts and the judicial system, making all the forensic assessments, which are essential to the investigation.

So, in order to allow a complete and precise assessment of every case, all the information's of public hospitals are useful when Legal Medicine has to elaborate the reports for the court.

Therefore, it is important that health care officials are properly trained in the area of domestic violence. Doctors must also screen for domestic violence, during physical examinations. Likewise, police and social workers must be trained to work with cases of domestic violence in order to detect, earlier, the warning signs and to give an adequate protection and support to the victims. 
The fear of failing once more, the fear of not being able to begin again a new project, the fear of not being able to take care of their children, the fear of becoming homeless and the lack of money, are enough motives for the victim to maintain the situation and to continue being battered. So, they are not able to decide for the court intervention and this ambivalence of the victims brings about difficulties to the criminal investigation. (Roberts \& White, 2007).

Very often, when the first aggression occurs, the victim doesn't believe that it is true. In most of the cases, she does nothing. She suffers in silence and says nothing to anybody. And, sometimes, she is being abused for years.

Psychologists and psychiatrists said that, when someone is beaten by an intimate partner, a frontier is passed. And when that frontier is passed, victims must react very strongly. Since that once created the fear of further attacks, it requires nothing more from the aggressor than a verbal threat to maintain the atmosphere of constant fear and anguish.

The feeling of impunity of the aggressor becomes propitious for more and more aggressions.

Everybody knows that, within the psychological damage brought on by abuse, is common to find symptoms of stress, depression and anxiety, which aggravates the situation and makes it more difficult to escape from the abuse.

We can say that self-esteem is the mental immunity system of man and when a victim looses her self-esteem; she also looses the capacity to complain and to take care of herself.

\section{The cause connection}

Aiming to establish the cause-connection it is crucial for the court to know which psychological damages are presented by a battered person and whether those damages were caused by the aggressive behaviour of the defendant.

Verbal abuse can be more damaging to a victim's psychological well-being, than physical abuse.

A forensic assessment must be considered, whenever the public prosecutor has the perception that a victim of violence is experiencing intense feelings of fear, shame, panic and anxiety. It also must be considered whenever he needs to understand the offender behaviour. An increased knowledge, which allowed the prosecutors and the judges to sentence properly, is the goal of these assessments.

So, the importance of the Legal Medicine for the investigation and for the make up of this crime is unavoidable.

The reports of Legal Medicine will inform the public prosecutors and the judges whether that victim presents symptoms of having been abused, what kind of symptoms she presents and if they could be caused by the aggressor's behaviour.

It is crucial to establish the cause connection because, without that, all the charges of psychological damages will fail.

Note that the specificities of this crime do not allow achieving a correct diagnosis of cause-effect in only one strike.

It is important to study the case, to know the aggressor and the victim, to understand how they interact, in order to find the causes of the aggressiveness, in such a way, that the court is able to understand what is going on.

So, the report can suggest, for instance, an intervention over the defendant, over the victim or over the family. 
In Coimbra, a new approach for the assessment of victims of psychological domestic violence had been executed with the guarantee of Legal Medicine.

\section{The assessment of victims and offenders}

The Delegation of Coimbra of the National Institute of Legal Medicine make the assessment of physical damages and delegates on the Family Violence Department of the Central Psychiatric Hospital of Coimbra the task of making the psychological and psychiatric assessment of victims of domestic violence and defendants sent by the Department of Investigation and Penal Action (DIAP) of Coimbra.

The Family Violence Department, besides making the reports of assessment, pronounces about the need and success of an intervention for the aggressors and for the victims and suggests to the court a program that the defendant, although in a coercive situation, must follow up.

The Portuguese legislation offers pre-trial mechanisms to give the offender the opportunity to review his behaviour, in order to maintain the relationship without further aggressions and injuries.

Before the charge and before the trial, the public prosecutor can put the defendant on probation. The aggressor is expected to adapt a new conduct and is aware of the coercive context. If he agrees with the conditions, and if he accomplishes those conditions, he will not be charged.

Considering the forensic report, these conditions can include, for the aggressors, the mandatory attendance of sessions of the Intervention Program in the Family Violence Department,.

\section{Final considerations}

The control system response must achieve different results: must rehabilitate the aggressor, protect and support the victim, and dependents, and make victims more comfortable and compensated after the law intervention.

We think that an efficient response to this kind of criminality requires an articulated and interdisciplinary intervention.

Besides judicial system, that has the coercion power; it must call for the cooperation of health and social systems.

The objective of bringing this to you, in a way, is to appeal for the decisive importance of Legal Medicine in the criminal investigation.

On the other hand, to call attention to the importance of the psychological and psychiatric assessment of aggressors and victims, and how this assessment can be decisive in sentencing someone, who commits a domestic violence crime.

I also believe that this subject requires a network response, adjoining all the actions of different profiles and areas. So far, it has been my fulfilling experience, at Coimbra.

Finally, I feel the need to state, that the duty of the judicial system, will only be effectively accomplished towards the victim, and to the society, if, after all, the victim experiences a change, for better, in her life. 


\section{References}

ATHENA - "Gender equality training for Decision-Makers, Educators and Leaders of NGO's" (2006) [ATHENA - Association for Education and Development of Women - Co.partner for "Wo-men: Gender Equality creates Democracy" EU Socrates Program Transnational Cooperation Project]. Available from http://www.gender-equality.webinfo.lt/ results/Curiculum.pdf

CIG - "Estudo sobre Homicídio Conjugal em Portugal" (2007) [CIG -Comissão para a Cidadania e Igualdade de Género] Available from http://www.analimacomunicacao.org/ disk/alc-PressReleases/institucional/CIG/PRESS\%2001\%20-\%2006072007\%20-\%20 Homicidi o\% 20Conjugal.pdf

HEALEY, K. “Batterer Intervention Program Approaches and Criminal Justice Strategies”- US Department of Justice - Office of Justice Programs -National Institute of Justice (1998)

MULLENDER, A. "La violencia doméstica. Una nueva visión de un viejo problema”. Barcelona: Paidós (2000)

ROBERTS, A. \& WHITE, B. "Battered Women and Their Families". New York, Springer Publishing Company (2007)

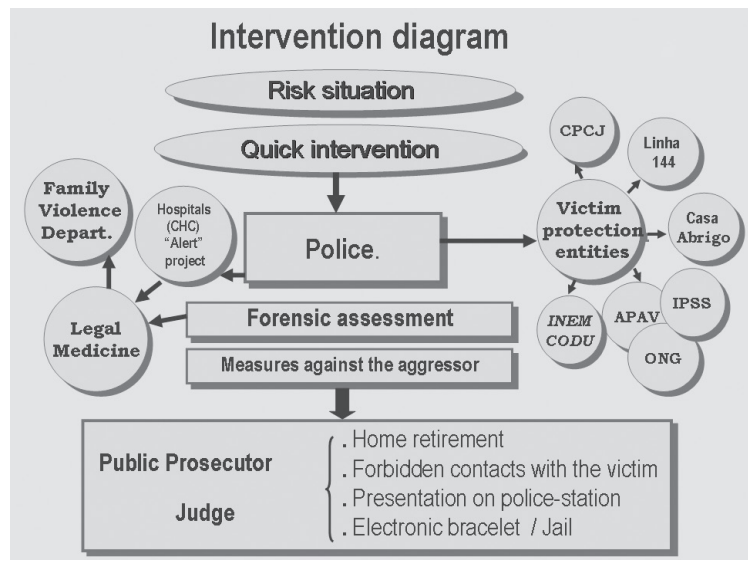

Figure - 1

Violence Group - Information, Investigation and Intervention

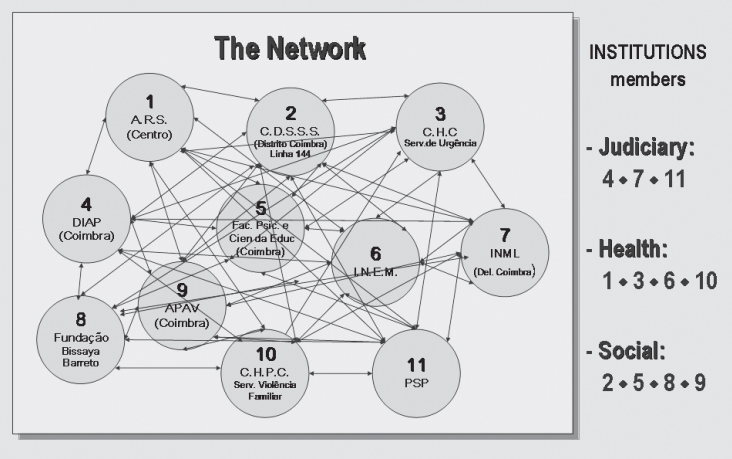

Figure - 2 